\title{
Urška Jeglič
}

\section{Neujemanja z islamskimi predpisi pokopa pri mus- limanih v Republiki Sloveniji}

\section{Deviations from Islamic burial regulations among Muslims in the Republic of Slovenia}

Povzetek: Muslimani so druga največja verska skupnost v Sloveniji, njihovo število pa se zaradi migracij in ustaljevanja v Sloveniji z leti povečuje. V skladu s tem se čedalje bolj odpira potreba po večjem razumevanju muslimanov, po razumevanju islamskih predpisov in verske prakse. Eden od pomembnejših verskih obredov je pogreb, ki se precej razlikuje od krščanskega pogreba. Tako muslimanom kakor nemuslimanom se postavljajo vprašanja, ali je udeležba na pogrebu drugače verujoče osebe iz verskega ozira dovoljenja. Hkrati pa pomanjkljivo razumevanje verskih običajev drugega v človeku zbuja strah in kot posledica tega zapira vrata medverskemu in medkulturnemu dialogu, pa tudi integraciji. Prispevek osvetljuje islamski pogled na smrt in na običaje, ki se navezujejo na islamsko pogrebno prakso. Posebno pozornost nameni opisu pogrebnih običajev pri muslimanih v Sloveniji in izpostavitvi in razlagi neujemanj z islamskimi predpisi, hkrati pa se dotakne problematike, vezane na muslimanska pokopališča v slovenskem prostoru.

Ključne besede: smrt v islamu, islamski pogreb, muslimani v Sloveniji, muslimanska pokopališča

Abstract: Muslims represent the second largest religious community in Slovenia, and their number has been increased over the years due to migration and settlement in Slovenia. Accordingly, there is a growing need for a greater understanding of Muslims, their understanding of Islamic precepts and religious practice. One of the more important religious rituals is a funeral, which is quite different from the Christian funeral. Both Muslims and non-Muslims are asking themselves whether attending the funeral of a non-religious person is religiously permissible. At the same time, the lack of understanding of the religious customs of the other arouses fear in man and consequently closes the door to interreligious and intercultural dialogue, as well as integration. This paper sheds light on the Islamic view of death and customs related to Islamic funeral practice. It pays special attention to the description of funeral customs among Muslims in Slovenia and the exposure and explanation of deviations from Islamic 
regulations, while also touching on issues related to Muslim cemeteries in Slovenia.

Key words: death in Islam, Muslims funeral, Muslims in Slovenia, Muslims cemeteries

\section{Uvod}

Islam velja za drugo največje verstvo na svetu, prav tako pa je islam drugo najbolj zastopano verstvo v Slovenji. Iz zadnjega popisa prebivalstva (Šircelj 2003) je razvidno, da živi v Sloveniji 47488 muslimanov. Mufti islamske skupnosti v Sloveniji, ${ }^{1}$ Nedžad Grabus (2011), opozarja, da omenjeni popis ni zajel sezonskih delavcev, in ocenjuje, da se število muslimanov v Sloveniji giba med 60000 do $70000 .^{2}$ Pri preučevanju omenjenih podatkov moramo imeti pred očmi tudi dejstvo, da je od zadnjega popisa slovenskega prebivalstva minilo skorajda dvajset let, število muslimanov pa se je v teh letih povečalo. Razloga za to sta predvsem dva: nadaljevanje priseljevanja muslimanskega prebivalstva v Slovenijo in nove generacije muslimanov, ki so že rojene v Sloveniji. ${ }^{3}$ Med potomce priseljencev iz popisa 2002 lahko prištevamo 6,5 \% prebivalcev Slovenije. Če bi se število priseljenih zmanjševalo, bi se s tem nižalo tudi število njihovih potomcev. Ker pa Slovenija v zadnjih letih vnovič doživlja porast priseljencev, se s tem povečuje tudi število potomcev migrantov. Po besedah Josipoviča $(2019,82)$ letne vrednosti migrantov ${ }^{4}$ v Sloveniji dosegajo tiste iz zlatih obdobij priseljevanja v Slovenijo, med katera sodi obdobje od leta 1975 do leta 1982.

Največ muslimanov se je na popisu glede na etično pripadnost opredelilo za Bošnjake (19 923), sledijo Muslimani (9238), Bosanci (5724), Albanci (5237), Slovenci (2804), neopredeljeni (2316) in Makedonci (507). ${ }^{5}$ Glede na omenjene podatke prihaja iz Bosne in Hercegovine 76,25 \% muslimanov, z 11,45 \% jim sledijo prebivalci iz Albanije, Slovenije (6,13 \%), Črne gore (1,3 \%) in iz Makedonije (1,1 \%). Kar 5,6 \% vprašanih se je razglasilo za neopredeljene. V nasprotju s tem Vobič Arličeva (2007, 114) pravi, da je kar 96 \% muslimanov, ki živijo v Sloveniji, po narodnosti Bošnjakov. V zadnjih letih se je povečalo število priseljencev iz Črne gore in s Kosova.

Če je bila še pred desetletji najpogostejša praksa, da so se priseljenci ob upokojitvi vrnili v svojo domovino, se ta trend precej spreminja. Slovenija je za mnoge

$1 \quad$ V register verskih skupnosti v Republiki Sloveniji so vpisane tri različne muslimanske skupnosti, med katerimi je najstarejša in najštevilnejša Islamska skupnost v RS, sledita ji Slovenska muslimanska skupnost in Slovenska islamska skupnost milosti. Kot društvi sta organizirani še dve islamski skupini: Društvo za promocijo islamske kulture Resnica Haq in El-imam in društvo Ahmadija.

2 Zalta $(2014,43)$ omenja, da je bilo leta 2014 v Sloveniji okrog 60000 muslimanov.

3 V Sloveniji živijo štiri generacije muslimanov.

$4 \quad$ Na zadnjem popisu se je za pripadnike islamske veroizpovedi izreklo $15 \%$ potomcev priseljencev in 5 $\%$ več priseljencev. Pri potomcih priseljencev se je glede na potomce zvišal delež neverujočih (za 4 \%), pa tudi tistih, ki niso pripadniki nobene veroizpovedi, kljub temu da se prištevajo med vernike $(1,9 \%)$, in tistih, ki na vprašanje niso želeli odgovoriti $(4,4$ \%). (Medvešek 2007, 46)

5 Pri tem moramo imeti pred očmi, da za 126325 oseb podatek ni poznan, 48588 pa jih na vprašanje ni želelo odgovoriti. 
priseljence postala novi dom, tu imajo svoje družine in krog prijateljev. V skladu s tem je v zadnjih desetletjih začelo naraščati število umrlih muslimanov v Sloveniji, pričakujemo pa lahko, da se bo številka z leti še povečala. Čeprav se po besedah imamov islamske skupnosti v Republiki Slovenijo še zmeraj veliko ljudi odloča za pokop rajnih v domovini, je odstotek tistih, ki jih pokopljejo v Sloveniji, iz leta v leto večji. Zaradi pričakovanega naraščanja islamskih pogrebov v Sloveniji se čuti čedalje večja potreba po rešenju odprtih vprašanj, vezanih na izvajanje islamskega pogreba v Sloveniji, ki je v slovenskem okolju slabo poznan in kot posledica tega tudi strah zbujajoč. Po drugi strani ostaja odprto tudi delno nerešeno vprašanje islamskih pokopališč v Sloveniji.

$\checkmark$ članku bomo podrobneje predstavili potek islamskega pogreba, s katerim se strinja večina slovenskih muslimanov. S trditvijo »Pokojne muslimane je treba pokopati po muslimanskih predpisih « se namreč strinja $91 \%$ anketiranih, od tega se $66 \%$ popolnoma strinja s trditvijo, $25 \%$ pa se s trditvijo samo strinja. Preostali anketirani se s trditvijo ne strinjajo (3\%) oziroma se popolnoma ne strinjajo (2\%), ne poznajo odgovora (3 \%) ali na vprašanje ne želijo odgovoriti (1 \%). ${ }^{6}$ Nadalje bomo predstavili potek islamskega pogreba v Sloveniji in izpostavili problematiko, vezano na obravnavano temo.

\section{Islamski pogled na smrt}

\subsection{Koran o smrti}

Koran, sveta knjiga muslimanov, se poleg doktrinalnih vprašanj in verskih predpisov dotika eksistencialnih tem, kamor uvrščamo tudi vprašanje smrti. Po učenju Korana se s smrtjo konča zgolj zemeljsko življenje, ki ga človek okuša neki določen čas ( $\mathrm{K} 2,36 ; 7,24-25)$. Koran pravi, da nobeno živo bitje ni nesmrtno, zato vsak okusi smrt in se vrne $k$ Alahu (K 4,78; 21,34-35; 29,57; 39,30; 62,8). Le Bog je tisti, ki lahko podeli in vzame življenje (K 40,68). „Vsako živo bitje umre po Božji volji, ob svojem času. « $(K 3,145)$ Ko nastopi smrtna ura, Alah dopusti, da človek zapusti svet (K $63,11)$. "Ko za nekoga med vami napoči smrtni čas, mu naši odposlanci brez oklevanja vzamejo dušo. Nato jih bodo odpeljali nazaj k Bogu, njihovemu resničnemu Gospodarju. On bo razsodil, saj najhitreje naredi obračun. « (K 6,60-62)

Kdor umre kot nevernik, se ne bo mogel odkupiti (K 3,91). Na sodni dan ga čaka pogubljenje in peklenski ogenj. Koran $(9,84)$ vernikom odsvetuje, da molijo za mrtve nevernike in da se udeležujejo njihovih pogrebov.

\subsection{Razumevanje smrti v islamu}

Islamska tradicija definira smrt kot ,pojav', ko telo postane mrzlo zaradi prenehanja srčne aktivnosti. To se ugotovi z empiričnim opazovanjem. Islam povezuje trpljenje pred smrtjo z aspektom odrešenja (Hedayat 2006, 1282). Glede na pou-

6 Rezultati ankete Verska praksa muslimanov v Republiki Sloveniji (Jeglič 2020). 
darek, ki ga daje islam skrbi za starše v bolezni in starosti, se od otrok ali staršev, če umira njihov otrok, pričakuje, da bo za umirajočega kolikor mogoče dobro poskrbljeno. Idealno je, če umirajoči muslimani umrejo doma, ob njih pa so navzoči njihovi najdražji. Pri počasnem umiranju imajo ljudje dovolj časa, da odpravijo zamere, jih oprostijo in prosijo ter molijo za umirajočega. Pri tem moli tudi umirajoči (če je tega zmožen), družina pa ga spodbuja, da vztraja v molitvi, vse dokler mu moči to dopuščajo. Pogost običaj je tudi branje sure Jasin. ${ }^{7} \mathrm{Ob}$ molitvi je priporočljivo, da so verniki obrnjeni proti Meki, svetemu kraju muslimanov. Omenjeni predpis velja tudi za umirajočega. Naloga svojcev je, da posteljo umirajočega obrnejo v pravo smer (Sheikh 1998, 138). Ko nastopi smrt, se telo ohladi, duša ${ }^{8}$ pa se loči od telesa. Islam tako ne priznava možganske smrti, saj telo pri tej smrti še ni ohlajeno (Hedayat 2006, 1285).

\section{Običaji, vezani na smrt in pogreb}

\subsection{Obredno umivanje}

Obredno umivanje je del verske prakse muslimanov, ki jo morajo opraviti pred po-

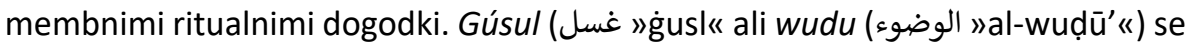
izvaja pri nečistosti pred opravljanjem džúme (arab. جمعة "al-ğum `a «), islamske skupinske molitve, pred ramazánom in pred vsakdanjim klanjanjem. Veljavno je le, če ima vernik iskren namen. Ob obrednem umivanju pokojnega je veljavnost gúsula odvisna od iskrenosti osebe, ki dejanje izvaja. Telo pokojnega je treba po islamskih predpisih pokopati v štiriindvajsetih urah oziroma takoj ko okoliščine to omogočajo. $V$ skladu s tem je $v$ točno določenem časovnem okviru treba opraviti obredno umivanje pokojnika. Razlogi za to so higienski, hkrati pa imajo religiološko noto. Tako se telo umrlega ,vrne' Stvarniku v kolikor možno spoštljivem stanju, saj se pri obrednem kopanju operejo pokojnikovi grehi (Ahaddour idr. 2017, 183).

Pred začetkom obrednega kopanja je pokojniku treba zapreti oči in usta. Obredno kopanje lahko opravljajo tako moški kakor ženske, a pod pogojem, da je pokojnik istega spola kakor oseba, ki izvaja gúsul. Islam uči, da umrli desettisočkrat bolj občuti bolečino. Zato se oseba, ki opravlja obredno umivanje trupla, pokojniku vnaprej opraviči, če ga bo ranila (184). Oseba, ki opravlja obredno umivanje pokojnega, mora biti tudi sama čista. Pred opravljanjem gúsula trebuh potisnejo

Sura 36.

8 Arabska beseda za dušo je náfs (arab. نَفْس ). Pod tem korenom se razumeta tudi nagon in duh. V teku zgodovine so se v islamu razvila različna razumevanja pojma duše. Tako je Ibn Arabi (13. stol.) govoril o zemeljski duši, ki se imenuje Duh Sveti in pomeni prvi razum. Al-Bajdavi je dodal, da duša nima telesa. Razloge za to navajajo štirje zgledi iz Korana in eden iz hadisov. Po njegovem mnenju je misleča duša izvor čistosti, ki se skupaj z duhom pretakala skozi telo in daje organom sposobnost funkcioniranja. Za dušo prav tako velja, da je ustvarjena, a drugače od telesa ni smrtna. Po teologiji al-Gazalija je duša pomemben faktor religioznega življenja. (Khoury 2005, 124-125)

9 Vsak vernik naj bi se obredno okopal vsaj enkrat na teden. Obvezno je to storiti ob nečistosti, na katero vplivajo ženska mesečna krvavitev (hajza), poporodna krvavitev (nifas), spolni odnosi in vsaka ejakulacija pri moškem (Džaferović 2006, 38). 
naprej, da iz njega odide odvečni zrak. Telo umijejo z vodo in milom najprej po desni, nato pa še po levi strani. Nato telo operejo s kafro in vodo in nazadnje le še z vodo. Telo posušijo in nadišavijo z mošusom. ${ }^{10}$ Muslimani verjamejo, da so otroci brez grehov, zato pri umrlih otrocih obredno kopanje ni potrebno, se pa večinoma kljub temu opravi.

\section{2 Ćefin-oblačilo pokojnega}

Maziljeno telo pokojnega je treba zakriti, to pa storijo s preprostim belim prtom ali platnom, ki se v bosanski tradiciji imenuje ćefin. ${ }^{11}$ Pri ženskah se uporabi pet ćefinov, pri moških pa trije. Ženskam se najprej zakrije predel telesa od glave do stopal. V drugem delu se zavije sredina trupa. Tretji ćefin prekrije del od popka do stopal, naslednji spet celotno telo od glave do stopal, zadnji pa zakrije lase. Ćefin je lahko odišavljen z mošusom. Pri moškem se izpusti zakrivanje las in posebno zavijanje sredine trupa oziroma oprsja.

\subsection{Islamski pokop}

Kakor že rečeno, je treba pokop pokojnih muslimanov opraviti v najkrajšem časovnem obdobju od nastopa smrti. Eden od islamskih predpisov tudi prepoveduje upepelitev trupla, izjema je dopuščena le ob smrtno nevarnih nalezljivih boleznih in pri zatiranju epidemije (Al- Daghistani [Jeglič 2020b]). Mrtvega pokopljejo na pokopališču (mezarlukom). Nekatere mošeje imajo ločene prostore, podobne vežicam, v katerih molijo za rajnega. Med molitvijo morajo verniki stati z desno stranjo obrnjeni proti Meki. Molitev, ki jo molijo, se imenuje salátu-l-dženazah ali pogrebna molitev. Pomeni bistvo pogreba, saj se v njej še zadnjič prosi za milost za umrlega. Učinek molitve je sorazmeren s številom molivcev. Imam udeležence na pogrebu vpraša, ali bodo, halalili', to pomeni, ali bodo odpustili umrlemu. Pogrebna molitev je sestavljena iz petih delov. Imam začne moliti »Allāhu ekber, Allāhu ekber «, temu sledi individualno recitiranje sure Fatiha v tišini. Drugi del molitve sestavlja ,salát Ibrahim'. Potem se izrečejo individualne prošnje za umrlega (dôva) in prošnje za vse pokojne Muslimane. Molitev se konča s pozdravom angelom. Po molitvi navzoči izrečejo naslednje izraze: »Inna lillāhi wa inna ilayhi raji'ūn«, ${ }^{12}$ "AAllāh yarziq sbar « ${ }^{13}$ in »Allāh ya'dzam al-'ajar« ${ }^{14}$ (Ahaddour idr. 2017, 188).

Po molitvi v sprevodu pospremijo umrlega do groba. Telo, z desno stranjo obrnjeno proti Meki, položijo v grob med molitvijo, v kateri molijo za dušo umrlega, hkrati pa se prek molitve krepi odnos med vernikom in pokojnim, razlog za to pa je prav vera, saj »ohranja tisto vez, ki se marsikomu zdi ob odprtem grobu dokončno pretrgana (Osredkar 2020, 86). V islamskem svetu velja tradicija, da se mrtvi za-

\footnotetext{
10 Mošus naj bi imel po verovanju muslimanov takšen vonj kakor raj. Uporablja se le v tistih geografskih območjih, kjer mošus uspeva.

$11 \vee$ arabščini se imenuje kàfàn, v turiščini pa kefen.

12 "Zagotovo, prišli smo od Alaha in k njemu se vračamo.»

13 "Alah naj nagradi potrpežljivost."

14 „Naj vas Alah nagradi.“
} 
kopavajo v tabutu, ,krsti’ iz petih desk, ki pa zgoraj ni odkrita. Pretirano žalovanje za umrlimi ni zaželeno. Islam tako kakor pri drugih stvareh tudi tukaj nagovarja k skromnosti in odpovedi, ki je »človekovo svobodno sprejemanje omejenosti« $(2019,667)$.

\subsection{Islamski grobovi}

Zaradi skromnosti, h kateri nagovarja islam, so muslimanski grobovi preprosti. Nekoliko drugačno tradicijo imajo resda šiiti, ki drugače od sunitov bolj ,častijo' pokojne in kot posledica tega krasijo njihove grobove. $V$ bosanski islamski tradiciji, ki je večinsko navzoča pri muslimanih v Republiki Sloveniji, je navada, da se postavi nagrobni znak, imenovan bašluk ali nišan, na katerega se zapišejo ime in priimek umrlega ter datuma rojstva in smrti. V skladu s tradicijo ima vsaka oseba svoj lastni grob. ${ }^{15}$ Hkrati pa ne poznajo nošenja sveč in rož na grobove, ki jih verniki v največjem številu obiščejo med praznovanjem ramazánskega bájrama.

\section{Pokop muslimanov v Republiki Sloveniji}

\subsection{Islamski pogrebi v Sloveniji}

Islamski pogreb je verski pogreb, ki ga lahko opravi islamski duhovnik, imenovan imam ali hodža. V Sloveniji se je obdržala balkanska praksa, da se verski pogreb lahko opravi le za tiste muslimane, ki so člani verske skupnosti. ${ }^{16}$ Večino umrlih pokopljejo imami, ki delujejo znotraj islamske skupnosti v Republiki Sloveniji; pred samim pogrebom preverijo, ali je bila članarina poravnana. Ob negativnem odgovoru je dolžnost svojcev, da pred pogrebom poravnajo članarino za umrlega ali pa odstopijo od verskega pogreba.

V islamskem svetu se je uveljavila judovska praksa, ki zapoveduje pokop umrlih v štiriindvajsetih urah. ${ }^{17}$ Zaradi urejanja potrebnih administrativnih zadev, morebitne obdukcije ${ }^{18}$ in splošnih pravil pokopavanja so pogrebi v štiriindvajsetih urah prej izjema kakor pravilo. Ljubljanski imam Senad Karišik pravi, da v trinajstih letih, odkar živi v Sloveniji, ni opravil niti enega pokopa v predpisanem časovnem okvi-

15 Izjeme so dovoljene v vojnem času in ob naravnih katastrofah.

16 V 13. členu Statuta Islamske skupnosti v Republiki Sloveniji (2019) je zapisano, da je član islamske skupnosti vsaka polnoletna oseba, ki sprejema islam za svoj način življenja. Za pridobitev naziva člana se je treba včlaniti v islamsko skupnost, to pa je mogoče le pod pogojem, da član živi znotraj teritorija, kjer ta skupnost deluje. Od aktivnih članov se zahteva redno plačevanje članarine. S plačevanjem članarine postanejo avtomatično člani islamske skupnosti vsi člani skupnega gospodinjstva, kljub temu pa je priporočljivo, da plača članarino vsak zaposlen član. Statut prepoveduje hkratno članstvo v drugih verskih organizacijah ali skupnostih. Člane, ki v javnosti sramotijo islamsko skupnost, lahko iz nje tudi izključijo.

17 Ali v najkrajšem možnem času.

18 Glede na islamske predpise obdukcija v očeh muslimanov ni najbolj zaželena. Eden od glavnih razlogov je preprečitev povzročanja dodatne bolečine umrlemu. Mohamed je namreč dejal, da je zlomiti kost umrlemu enako boleče, kakor če se to naredi živemu človeku. Muslimani v Sloveniji v veliki meri podpirajo obdukcijski pregled umrlega. 
ru. Muslimani so mi v intervjujih dejali, da so pogrebne službe resda kdaj pripravljene opraviti pokop v štiriindvajsetih urah, a se za takšno prakso odloči malo svojcev. Najpogostejši razlog je to, da si želijo imeti na pogrebu tudi sorodnike, ki živijo v tujini, ti pa si morajo pred prihodom v Slovenijo zagotoviti dopust in pripotovati v Slovenijo.

Pogrebna verska praksa vsebuje gúsul. Telo pokojnega je priporočljivo obredno umiti v najkrajšem možnem času, v Sloveniji pa se opravi lahko šele po tem, ko imam preveri članstvo pokojnega in ko se domačim s pogrebno službo uspe dogovoriti za pogreb. Ob smrti muslimana gúsul opravi imam, skupaj z ožjimi sorodniki, včasih pomaga tudi pogrebna služba. Ob smrti muslimanke pa obredno kopanje opravijo ženske. Medtem ko so mi imami v intervjujih zaupali, ${ }^{19}$ da nimajo večjih težav pri izvajanju obrednega umivanja, je eden od muslimanov opisal izkušnjo pogreba svojega očeta z besedami: „Prišel sem v prostor, namenjen obredni pripravi muslimanov. Velika in prazna soba. Neugledna. Z veliko železno mizo in gumijasto cevjo za vodo. Kakor da smo vstopili v tovarniško halo. « (Baltić idr. 2008,155 ) To je opis razmer v prostoru za obredno umivanje v Ljubljani, v katerem se islamska skupnost sooča tudi z drugimi izzivi (glej 4.2). Prostori za versko umivanje se v posameznih krajih razlikujejo, medtem ko je praksa, vezana na pogreb, enaka.

Truplo pokojnega se po obrednem umivanju postavi v krsto. Sledi sprevod do groba pokojnega, pri katerem se opravi pogrebna molitev. Zaradi močne povezave z Bosno muslimani v Sloveniji ohranjajo prakso, ki so jo oni sami ali njihovi predniki prinesli iz Bosne. Hkrati pa so v več desetletjih, odkar so muslimani navzoči v Sloveniji, začele nastajati tudi razlike med versko prakso v Bosni in v Sloveniji; to lahko opazimo tudi pri pogrebni molitvi, ki se v Sloveniji opravlja na grobu, v nasprotju z balkansko prakso, ${ }^{20}$ pri kateri opravljajo molitve za pokojne muslimanke na domovih, za pokojne muslimane pa v džamiji. Bringa omenja (1997, 200), da se je v Bosni razvila tradicija ženskih in moških pogrebnih molitev. Ženski tevhidi ${ }^{21}$ so daljši, opravljajo se doma in ne v džamiji, vse žene uporabljajo le en tespih. Ker primanjkuje bul, tevhide vodijo tudi druge ženske, po opravljenih tevhidih pa vedno sledi namáz in druženje ob hrani. Žene, ki so bolj pobožne, sedijo bliže buli, medtem ko so druge obrnjene k njej s strani. Moški se po opravljenih tevhidih iz džamije napotijo domov (200-201). Po opravljeni molitvi se muslimani odpravijo na pogreb. Glede na običaje na pogreb odidejo le moški, žene pa v tem času ostanejo doma in medtem opravljajo tevhide in mevlud. Za dušo umrlega se opravi pet tevhidov. Prvi se opravi na dan pogreba, takoj ko umrlega odnesejo iz hiše oziroma bolnice. Ritual se ponovi na sedmi in na štirideseti dan po smrti. Četrti tevhid se opravi šest mesecev po smrti, zadnji pa na prvo obletnico $(197 ; 200)$.

19 Vsi intervjuji s slovenskimi imami so bili narejeni v sklopu ankete ob raziskavi za doktorsko disertacijo med junijem in oktobrom 2020 in se hranijo v avtoričinem osebnem arhivu.

20 Hkrati opažamo, da so razlike navzoče tudi znotraj Bosne in drugih balkanskih držav z islamskim prebivalstvom. Posebno velike razlike obstajajo med urbanim in vaškim predelom, ki je ostaja še veliko bolj tradicionalen.

21 Tevhid poleg izpovedi vere pomeni tudi pobožno molitev za rajne. 
Nenavzočnost žensk in otrok na pogrebu izhaja iz želje po zaščiti bolj ranljivih skupin, saj ti obredi veljajo za bolj čustvene in občutljive. Položitev pokojnega v grob bi jih lahko zelo prizadela, glasno jokanje kot posledica tega pa bi vznemirilo dušo pokojnega. V koraku z modernizacijo in z brisanjem razlik med moškimi in ženskami se čedalje več žensk udeležuje pogrebov (Sheikh 1998, 138-139; Hedayat 2006, $1285 ; 1287)$. Ženske se lahko islamskega pogreba udeležijo tudi v Sloveniji, meni tajnik islamske skupnosti Nevzet Porić (Žunić 2016), saj islamsko učenje tega ne prepoveduje. ${ }^{22}$ Slovenski imami se strinjajo, da bi bila takšna prepoved v demokratični družbi nesmiselna. Hkrati se zavedajo potrebe, da se muslimani čimbolj integrirajo v slovensko okolje. Zaradi možnosti prilagoditve verskih predpisov tradicije, ki jih hanifejska pravna šola, kateri sledijo tudi znotraj islamske skupnosti, dovoljuje, pa je takšna sprememba povsem legalna. Islamskih pogrebov v Sloveniji se udeležujejo tudi nemuslimani. Govorimo o sodelavcih, o prijateljih in o sosedih, s katerimi je bil pokojni povezan. Imami vidijo v tem dobro priložnost za medkulturno in medversko srečanje, hkrati pa tudi svojim vernikom svetujejo, da se lahko udeležijo pogreba drugače verujoče osebe.

Opravljanje skupinskih molitev za dušo umrlega na domu njegove družine je navzoče skorajda po vsem islamskem svetu. Prek te molitve se gradi odnos s skupnostjo, hkrati pa navzočnost skupnosti svojcem pokojnega pomaga, da se ne predajajo pretirani žalosti. Kljub temu da se čedalje več muslimanov daje pokopati v Sloveniji, je več kakor polovica pokojnih pokopanih v rojstnem kraju. Tedaj se $v$ Sloveniji velikokrat opravi obredna molitev za pokojnega, saj se celotna skupnost ne more odpraviti na pogreb v tujo državo.

Slovenski imami so mi v pogovorih zaupali, da je število islamskih pogrebov v Sloveniji majhno, številka pa je glede na odbore sorazmerna s številom članov. Največ, približno štirideset islamskih pogrebov, opravi ljubljanski imam, ki dodaja, da se je številka leta 2020 nekoliko povečala, saj sta pandemija kovida 19 in zaprtje državnih meja nekaterim preprečila izvoz trupel v tujino. V preostalih odborih se število giblje med tremi do desetimi pogrebi na letni ravni, z urejanjem novih zemljišč in glede na dejstvo, da je Slovenija domovina za čedalje več muslimanov, pa se bo število z leti povečalo.

\subsection{Muslimanski grobovi in vprašanje muslimanskih pokopališč v Sloveniji}

Za islamska pokopališča je značilno, da so preprosta, prav tako so skromni grobovi. V navadi je, da se postavi nagrobni znak, imenovan bašluk ali nišan, na katerega se zapišejo ime in priimek umrlega ter datuma rojstva in smrti. Na slovenskih bašlukih se pred imenom in priimkom zapiše tudi merhum ali merhuma. ${ }^{23}$ Če je oseba v življenju opravila hádž, si je s tem pridobila nadimek hádži, to pa je prav tako zapisano na nišanu. Na islamskih spomenikih najdemo tudi islamski simbol (polmesec in petkraka zvezda) in ime prve sure, El-Fatiha. V skladu s tradicijo ima

\footnotetext{
22 Nenavzočnost žensk na pogrebih je sad pogrebne pravne prakse.

23 Arab. مرحوم, »v božji milosti巛.
} 
vsaka oseba svoj grob. Bosanska muslimanska tradicija ${ }^{24}$ ne pozna polaganja rož in sveč na grobove, ki jih verniki v največjem številu obiščejo ob praznovanju ramazánskega bájrama. Kljub temu pa lahko ob obisku muslimanskih grobov opazimo veliko rož, sveč, pa tudi glinenih angelčkov. Imami odgovarjajo, da so tudi nekateri muslimani prevzeli krščansko tradicijo nošenja rož na grobove, večkrat to storijo tudi nemuslimanski prijatelji, to pa nam znova nakazuje interakcijo muslimanov s slovenskim okoljem in medkulturni dialog.

V Sloveniji so se že pred leti odprle debate o nerešeni problematiki, vezani na muslimanska pokopališča, pri tem pa so največje težave v prestolnici. Grabus $(2011,10)$ omenja, da je v preteklosti na ljubljanskih Žalah že stalo muslimansko pokopališče, ki bi naj bilo zaprte narave. Zaradi uničenja nišanov na grobovih so izbrisani materialni dokazi o več kakor štiristo pokojnih muslimanih na ljubljanskem pokopališču, ki so bili pokopani med obema svetovnima vojnama in v začetku obdobja hladne vojne. Na Žalah so muslimane lahko pokopavali tudi pozneje, a je med vojno $v$ Bosni in Hercegovini zmanjkalo prostora na dodeljeni parceli. Islamska skupnost v Republiki Sloveniji je leta 2007/2008 izdala prošnjo za novo dodelitev parcele na ljubljanskih Žalah, a do danes pozitivnega odgovora še niso prejeli. Pokojne muslimane sedaj pokopljejo tam, kjer je prostor. Po Grabusovih besedah (2011) je rešitev vprašanja islamskih pokopališčih eden od pomembnejših ciljev islamske skupnosti, ki pa je bil zaradi graditve prve džamije v Sloveniji postavljen na stranski tir, saj je kot prvo treba poskrbeti za žive vernike. Džamija in Muslimanski kulturni center sta svoja vrata odprla februarja 2020.

Vprašanja glede pokopališč so dobro ureja na Jesenicah, v Postojni in v Mariboru. Svojo parcelo imajo tudi koprski muslimani, kjer imajo pokojni lahko tudi nagrobnike. Koprski imam Jusić zadovoljen pove, da so dodatne prostore dobili tudi na novem koprskem pokopališču. Pred leti so vprašanje o dodelitvi parcel na lokalnih pokopališčih učinkovito rešili v Celju, v Trbovljah in v Kranju (leta 2013). Celjski imam Nazif Topuz omenja, da je bilo do oktobra 2020 pokopanih približno dvajset vernikov, prostora je še za približno sto pokojnih. Po drugi strani pa nimajo urejenih prostorov za obredno umivanje pokojnika, ki ga opravijo v prostorih komunalne službe ali pa v bolnišnici. Prostorska stiska teži tudi muslimane $v$ Velenju. Prošnjo za parcelo za islamske grobove so predložili tudi muslimani v Novem mestu, a je bila njihova vloga zavrnjena. Novomeški imam Adnan-ef. Merdanović pravi, da na prošnjo niso ugovarjali in da je vesel dobrih odnosov s tamkajšnjo komunalno službo, ki dovoli obredno umivanje pokojnih.

Leta 2007 je islamska skupnost v Republiki Sloveniji realizirala svoj cilj zamenjave železnih križev z nišani, ki so bili postavljeni na skromnih grobovih vojaškega muslimanskega pokopališča iz prve svetovne vojne v Logu pod Mangartom. Tam naj bi bilo pokopanih okrog 850 muslimanskih vojakov.

$24 \mathrm{~V}$ nekaterih islamskih kulturah je polaganje rož del islamske verske prakse. 


\section{Sklep}

S člankom smo želeli prikazati neujemanja pri izvajanju islamskega pogreba in pri običajih, vezanih na pogrebe pri muslimanih, živečih v Sloveniji, in predstaviti razloge za to. Najbolj vidna neujemanja opazimo na šestih področjih, ki jih lahko razdelimo v dve skupini. Neujemanja v prvi skupini so posledica zakonov v zvezi z izvajanjem pogrebne in pokopališke dejavnosti v Sloveniji, v drugi pa so vidni znaki prilagajanja muslimanov na življenje v Sloveniji in prevzemanja navad iz okolja, v katerem živijo. Govorimo o dialogu na individualni ravni, kakor »se dogaja v vsakdanjem življenju kristjanov in muslimanov, ki živijo v nekem skupnem okolju. Takšen dialog se dogaja, ko se verniki soočajo med seboj v vsakodnevnih situacijah, se pogovarjajo in spoznavajo. V ospredju je predvsem sodelovanje in priznavanje drug drugega zaradi želje po mirnem sobivanju dveh različnih verskih skupnosti na enem kraju, « pravi Osredkar $(2018,29)$.

Med neujemanja v prvi skupini sodijo pokopi, ki se opravijo po preteku štiriindvajsetih ur od nastopa smrti, obvezno pokopavanje v krsti in lega dodeljenih parcel. V Sloveniji je pogreb v enem dnevu po besedah imamov prej izjema kakor pravilo, hkrati pa je v neskladju s 15. členom Zakona o pogrebni in pokopališki dejavnosti (2016), ki pravi, da se pokop opravi, ko preteče najmanj 36 ur od nastopa smrti. Prav tako je truplo glede na 17. člen omenjenega zakona nemogoče pokopati v tabutu. Zaradi nerešene situacije $z$ dodelitvijo parcel za muslimane na slovenskih pokopališčih in zaradi dodeljevanja teh parcel na nepremišljenih lokacijah pokopavanje muslimanov z desno stranjo proti Meki ni vedno izvedljivo. Od neujemanj z islamsko pogrebno prakso, ki so povezana s prilagoditvijo na način življenja v Sloveniji, so med najbolj izstopajočimi spremembami navzočnost žensk na pogrebih, obiskovanje pogrebov muslimanov drugače verujočih in prinašanje cvetja, sveč in drugih predmetov na grobove. Na tem mestu še omenimo, da so pogrebni rituali del verske prakse, ki je vedno živa in kot posledica tega spreminjajoča se, zato torej kot takšna ni v nasprotju z dogmatičnimi načeli islama.

\section{Reference}

Ahaddour, Chaīma, Stef Van den Branden in Bert Broeckaert. 2017. Purification of body and soul for the next journey: Practices surrounding death and dying among Muslim women. OMEGA - Journal of death and dying 76, št. 2:169200.

Baltić, Admir, Tatjana Pezdir in Safet Alibeg. 2008. Prepletanje kultur: Slovenija v Bosni in Hercegovini, Bosna in Hercegovina v Sloveniji. Ljubljana: Bošnjaška kulturna zveza Slovenije.

Bringa, Tone. 1997. Biti musliman na bosanski način. Sarajevo: Dani.

Džaferović, Sejfullah Ervin. 2006. Spoznajte islam. Ljubljana: Studio Print.
Grabus, Nedžad. 2011. Sožitje je naša pot: Intervjuji in govori muftija dr. Nedžada Grabusa. Ljubljana: Kulturno-izobraževalni zavod Averroes.

Hedayat, Kamyar. 2006. When the spirit leaves: Childhood death, grieving, and bereavement in Islam. Journal of palliative medicine 9, 6:12821291.

Jeglič, Urška. 2020. Analiza rezultatov raziskave Verska praksa muslimanov v Republiki Sloveniji za namen doktorske disertacije. Osebni arhiv Urške Jeglič.

- - - 2020b. Intervju z dr. Raidom Al-Daghistinijem o islamski verski praksi. 16. oktober. Osebni arhiv Urške Jeglič. 
Josipovič, Damir. 2019. Spremembe etnične in migracijske ter izobrazbene strukture prebivalstva mestne občine Ljubljana - primerjava podatkov popisov 1991, 2002 in 2015. Razprave in gradivo, revija za narodnostna vprašanja, št. 82:25-47.

Khoury, Adel Theodor. 2005. Leksikon temeljnih religijskih pojmova: Židovstvo, kršćanstvo, islam. Zagreb: Prometej.

Koran. 2005. Prev. Erik Majaron. Tržič: Učila International.

Medvešek, Mojca. 2007. Kdo so potomci priseljencev z območja nekdanje Jugoslavije? Razprave in gradivo, št. 53/54:28-67.

Osredkar, Mari Jože. 2018. V začetku je bil dialog. Bogoslovni vestnik 78, št. 1:17-31.

- - . 2019. Religija kot izziv za transhumanizem. Bogoslovni vestnik 79, št. 3:657-668.

- - - 2020. "S smrtjo se odnos spremeni, ne pa uniči«: Življenje in teologija Guyja Lafona. Bogoslovni vestnik 80, št. 1:73-88.

Sheikh, Aziz. 1998. Death and dying - a Muslim perspective. Journal of the royal society of medicine 91, marec: 38-140.

Statut Islamske skupnosti v Republiki Sloveniji. 2019. Ljubljana: Arhiv Islamske skupnosti v Republiki Sloveniji.

Šircelj, Milovoja. 2003. Verska, jezikovna in narodna sestava prebivalstva Slovenije: Popisi 1921-2002. Ljubljana: Statistični urad Republike Slovenije.
Vobič Arlič, Nina. 2007. Slovenska nacionalna identiteta in islam. Časopis za kritiko znanosti, domišljijo in novo antropologijo 37, št. 235/236:114-126.

Zakon o pogrebni in pokopališki dejavnosti. 2016. Pravno-informacijski sistem, http://www.pisrs. si/Pis.web/pregledPredpisa?id=ZAKO6938 (pridobljeno 15. 11. 2020).

Zalta, Anja. 2014. Islam in Slovenia: The history of Muslim presence and characteristics of the Muslim population of Slovenia. V: Mesult Idriz in Osman Bakar, ur. Islam in Southeast Europe: Past reflections and future prospects, 39-45. Begawan: Universiti Brunei Derussalam.

Žunić, Nataša. 2016. Polovico slovenskih muslimanov na zadnji počitek odpeljejo v Bosno, Makedonijo ali Kosovo. RTV SLO, 13. 11. https:// www.rtvslo.si/slovenija/polovico-slovenskih-muslimanov-na-zadnji-pocitek-odpeljejo-v-bosno-makedonijo-ali-kosovo/407136 (pridobljeno 16. 11. 2020). 